\title{
A Review on Applications of Imaging Synthetic Aperture Radar with a Special Focus on Cryospheric Studies
}

\author{
Shridhar D. Jawak', Tushar G. Bidawe ${ }^{2}$, Alvarinho J. Luis ${ }^{1}$ \\ ${ }^{1}$ Polar Remote Sensing Division, Earth System Science Organization (ESSO), National Centre for Antarctic \& \\ Ocean Research (NCAOR), Ministry of Earth Sciences, Vasco-Da-Gama, India \\ ${ }^{2}$ Department of Civil Engineering, Symbiosis Institute of Technology, Symbiosis International University, Pune, \\ India \\ Email: shridhar.jawak@gmail.com, tush11091@gmail.com, alvluis@ncaor.gov.in
}

Received 22 May 2015; accepted 27 June 2015; published 30 June 2015

Copyright (C) 2015 by authors and Scientific Research Publishing Inc.

This work is licensed under the Creative Commons Attribution International License (CC BY).

http://creativecommons.org/licenses/by/4.0/

(c) $\underset{\mathrm{EY}}{\mathrm{ir}}$ Open Access

\section{Abstract}

The cryosphere is the frozen part of the Earth's system. Snow and ice are the main constituents of the cryosphere and may be found in different states, such as snow, freshwater ice, sea ice, permafrost, and continental ice masses in the form of glaciers and ice sheets. The present review mainly deals with state-of-the-art applications of synthetic aperture radar (SAR) with a special emphasize on cryospheric information extraction. SAR is the most important active microwave remote sensing (RS) instrument for ice monitoring, which provides high-resolution images of the Earth's surface. SAR is an ideal sensor in RS technology, which works in all-weather and day and night conditions to provide useful unprecedented information, especially in the cryospheric regions which are almost inaccessible areas on Earth. This paper addresses the technological evolution of SAR and its applications in studying the various components of the cryosphere. The arrival of SAR radically changed the capabilities of information extraction related to ice type, new ice formation, and ice thickness. SAR applications can be divided into two broad classes-polarimetric applications and interferometric applications. Polarimetric SAR has been effectively used for mapping calving fronts, crevasses, surface structures, sea ice, detection of icebergs, etc. The paper also summarizes both the operational and climate change research by using SAR for sea ice parameter detection. Digital elevation model (DEM) generation and glacier velocity mapping are the two most important applications used in cryosphere using SAR interferometry or interferometric SAR (InSAR). Spaceborne InSAR techniques for measuring ice flow velocity and topography have developed rapidly over the last decade. InSAR is capable of measuring ice motion that has radically changed the science of glaciers and ice sheets. Measurement of temperate glacier velocities and surface characteristics by using airborne and space-borne interferometric satellite images have been the significant application in glaciology and cryospheric studies. Space-borne InSAR has contributed to 
major evolution in many research areas of glaciological study by measuring ice-stream flow velocity, improving understanding of ice-shelf processes, yielding velocity for flux-gate based massbalance assessment, and mapping flow of mountain glaciers. The present review summarizes the salient development of SAR applications in cryosphere and glaciology.

\title{
Keywords
}

\author{
Cryosphere, Remote Sensing, Synthetic Aperture Radar (SAR), Polarimetric SAR, Interferometric \\ SAR
}

\section{Introduction}

Synthetic aperture radar (SAR) was invented by Carl Wiley in 1951 [1]. The SAR sequentially transmits pulses of microwave radiation on the Earth's surface and collects a coherent sum of backscattered signals at radar antenna which forms an image that is synthesized by the large motion of the sensor system. An appropriate coherent combination of the received signals allows the construction of a virtual aperture that is much longer than the physical antenna length (hence the name "synthetic aperture"). In other words, SAR is an airborne or spaceborne side-looking radar (SLR) system which uses the flight path of the platform to stimulate a large antenna or aperture electronically, which helps to generate high resolution RS imagery. Since SAR provides its own signal (active remote sensing sensor), it overcomes some of the basic problems associated with traditional passive remote sensing (RS). SAR is unaffected by cloud cover or variation in solar illumination, and thus can collect data during day or night. Additionally, under certain environmental circumstances, SAR can partly penetrate arid and hyper-arid surfaces, which can be used to explore subsurface features of the Earth. Although radar does not penetrate standing water, it can reflect the surface features of oceans, lakes, and other water bodies and may sometimes provide information about the bottom features of the water body. In the polar regions, sea ice signatures are detected by SAR. Satellites like Radarsat-1, Earth Remote Sensing Satellite 1 (ERS-1), ERS-2, Environmental Satellite (Envisat), Japanese Earth Resources Satellite (JERS), and the newest generation of SAR systems like Radarsat-2 and Terra SAR-X can be effectively used for studying cryosphere. Part of the emitted radar energy (5.6 cm wavelength) directed at the ocean is reflected back to the satellite because of the roughness of the sea surface and is imaged as a gray speckle. SAR images have huge applications in RS for the mapping of the earth's surface. SAR has the capability of RS in all-weather and day-or-night at a finer resolution. SAR image provides information different from that of optical sensors operating in visible and infrared regions of the electromagnetic spectrum.

The SAR principle was discovered in the early 50s. After that, there has been a rapid development, which results in launch of air and space-borne SAR systems, e.g., RORSAT (SAR, Soviet Union, 1967-1988), SAR Lupe 1-5 (SAR satellites of the German Air Force), COSMO-SkyMed (SAR, Italy, 2007), and TecSAR (SAR, Israeli, 2008). Essentially, in the 50s SAR was used more for military reconnaissance and less for civilian applications [2]. In India, the first indigenous all-weather Radar Imaging Satellite (Risat-1) was launched successfully in 2012. Because of its day-night and all-weather monitoring capability, Risat-1 images have been used to provide information on agriculture, forestry, and soil moisture mapping and disaster management [2]. The data provided by SAR sensors are superior because the quality of data is insensitive to clouds and/or smoke, and other atmospheric conditions. Therefore, multi-temporal SAR imagery is an essential tool for disaster prevention and any other ecological applications, especially in change detection studies. Various oceanographic applications such as oil slick detection, surface waves, circulation, etc. have demonstrated the ability of SAR to address different problems, which lead to the successful launch of a range of space-borne SARs (Seasat in 1978, ERS-1 in 1995, ERS-2 in 1995, Radarsat-1 in 1995, Envisat in 2002, etc.). The oceanic features commonly detected on SAR imagery include surface waves, mesoscale ocean circulation structures such as eddies and currents, oil slicks, ships and their wakes, internal waves, and coastal bathymetry. The SAR is so sensitive to the interaction of the wind with the ocean surface that, in addition to wind speed, patterns and structures within the atmospheric boundary layer can be mapped. An algorithm has been developed for the cognitive process of very high resolution ocean surface winds, ocean wave spectra as well as detection of coastal and deep sea ships using RISAT-1 
SAR data [3]. In the last two decades, SAR polarimetry has shown a research potential through airborne research campaigns, which lead to the space-borne missions that offer fully polarimetric modes (i.e., ALOSPALSAR, TerraSAR-X and Radarsat-2). Therefore, automated analysis procedures are required, which typically involve the classification task. However, SAR data classification is known to be challenging because of speckle, which results in a large variation of the backscatter across neighboring pixels within the same distributed target (e.g., a field of wheat) [4]. Table 1 shows the various popular SAR missions used in RS applications.

The most important active microwave RS instrument for ice monitoring is the SAR which provides high-resolution images of the Earth's surface. The development of airborne-SAR observing systems during the 1970s and 1980s paved the way for the satellite SAR systems Seasat, ALMAZ-1, JERS-1, ERS-1 and -2, Radarsat-1 and Envisat. ERS-1 and -2 and Radarsat-1 have been operational for many years and have provided large amounts of SAR images for sea ice observation, in particular, the Radarsat ScanSAR data. In 2003, Envisat began providing multi-mode SAR data. Other active microwave methods used for ice observations include scatterometers, radar altimeters and side-looking real aperture radars (SLR) [5]. Some radar-altimeters (like CryoSat/ SIRAL) employ synthetic aperture and/or interferometric techniques; their reduced footprint allows mapping of rougher surfaces like polar ice. Wesche et al. [6] used the mosaic of the Radarsat-1 Antarctica Mapping Project (RAMP) Antarctic Mapping Mission 1 (AMM) to classify the coastline of Antarctica in terms of surface structure patterns close to the calving front. The resulting map of the classified calving fronts provides a detailed picture of crevasse formation and the observed dominant iceberg shapes. Jezek et al. [7] compiled the RAMP mosaic of Antarctica.

Septhon et al. [8] proposed segmentation of SAR imagery of sea ice. Young et al. [9] used SAR for nearcoastal iceberg distribution in East Antarctica. Wesche and Dierking [10] proposed a method for iceberg detection in SAR images in two test regions of the Weddell Sea, Antarctica, while Willis et al. [11] proposed an iceberg detection method using ERS-1 SAR. Mapping of the ice motion in Antarctica using SAR data was done elsewhere [12], while Rignot et al. [13] compiled a SAR interferometry (InSAR)-based Antarctica ice velocity

Table 1. List of popular SAR missions.

\begin{tabular}{|c|c|c|c|c|c|c|}
\hline Satellite & Country (Year) & $\mathbf{F}$ & W & IA & $\mathbf{P}$ & SR \\
\hline SEASAT (L) & USA (1978) & 1.275 & 23.5 & 23 & $\mathrm{HH}$ & 25 \\
\hline SIR-A (L) & USA (1981) & 1.275 & 23.5 & 50 & $\mathrm{HH}$ & 40 \\
\hline SIR-B (L) & USA (1984) & 1.275 & 23.5 & $15-65$ & $\mathrm{HH}$ & 25 \\
\hline ERS - 1/2 (C) & Europe (1991/95) & 5.25 & 5.7 & 23 & VV & 30 \\
\hline ALMAZ (S) & USSR (1992) & 3.0 & 10 & $30-60$ & $\mathrm{HH}$ & $5-7$ \\
\hline JERS-1 (L) & Japan(1992) & 1.275 & 23.5 & 39 & $\mathrm{HH}$ & 20 \\
\hline SIR-C/X-SAR (L,C,X) & $\begin{array}{l}\text { USA (1994) } \\
\text { Germany }\end{array}$ & $\begin{array}{l}\text { L-1.25 } \\
\text { C-5.3 } \\
\text { X-9.6 }\end{array}$ & $\begin{array}{l}23.5 \\
5.7 \\
3\end{array}$ & $\begin{array}{l}15-55 \\
54\end{array}$ & $\begin{array}{l}\mathrm{HH}, \mathrm{HV}, \\
\mathrm{VH}, \mathrm{VV}, \\
\mathrm{VV}\end{array}$ & 30 \\
\hline Radarsat-1 (C) & Canada (1995) & 5.3 & 5.7 & $20-50$ & $\mathrm{HH}$ & $10-100$ \\
\hline $\operatorname{SRTM}(C, X)$ & $\begin{array}{l}\text { USA (2000) } \\
\text { Germany }\end{array}$ & $\begin{array}{l}\text { C-5.25 } \\
\text { X-9.6 }\end{array}$ & $\begin{array}{l}5.7 \\
3\end{array}$ & $\begin{array}{l}54 \\
54\end{array}$ & $\begin{array}{l}\mathrm{HH}, \mathrm{VV} \\
\mathrm{VV}\end{array}$ & 30 \\
\hline ENVISAT (C) & Europe (2002) & 5.25 & 5.7 & $15-45$ & HH, HV, VH, VV & $20-100$ \\
\hline Radarsat-2 (C) & Canada (2007) & 5.4 & 5.6 & $24-50$ & $\mathrm{HH}, \mathrm{HV}, \mathrm{VH}, \mathrm{VV}$ & $3-100$ \\
\hline Terra-SAR (X) & Germany (2007) & 9.65 & 3.1 & $20-55$ & $\mathrm{HH}, \mathrm{VV}$ & $0.24-260$ \\
\hline Tandem-X (X) & Germany (2010) & 9.65 & 3.1 & $20-55$ & $\mathrm{HH}, \mathrm{VV}$ & $1-16$ \\
\hline RISAT-1(C) & India (2012) & 5.35 & 5.7 & $15-50$ & HH, HV, VH, VV & $3 / 6 / 9 / 25 / 50$ \\
\hline ALOS-2 (L) & Japan (2014) & 1.2 & 22.9 & $8-60$ & $\mathrm{HH}, \mathrm{HV}, \mathrm{VH}, \mathrm{VV}$ & $10-100$ \\
\hline
\end{tabular}

[Abbreviations: F (Frequency, GHz), W (Wavelength, centimeter), IA (Incident angle, degree), P (Polarization Type), SR (Spatial resolution, m), H (horizontal), V (Vertical)]. 
map. Fricker et al. [14] studied iceberg calving from the Amery ice shelf, East Antarctica using SAR technology. Recently, Jawak and Luis [15] proposed the potential application of NASA-ISRO SAR (NISAR) in cryospheric studies, to demonstrate the capability of SAR for mapping calving fronts of Antarctica.

\section{Polarimetric SAR Classification}

A Polarimetric SAR (PolSAR) is a radar that alternately transmits horizontally and vertically polarized waves and receives both the polarizations [16]. The recent launch of space-borne (TerraSAR-X, Radarsat-2, ALOSPALSAR, RISAT) and airborne (SIRC, AIRSAR, UAVSAR, PISAR) polarimetric radar sensors, with the ability of imaging through the day and night in almost all weather conditions, has made PolSAR image interpretation and analysis an active area of research. PolSAR image classification is sensitive to object orientation and scattering properties. In the case of SAR, the radar image results from processing the raw data (i.e., after forming the synthetic aperture) and represents a measure of the scene reflectivity. The classification of SAR polarimetric data has been done by different researchers in various different ways. Airborne visible/infrared imaging spectrometer (AVIRIS) and L-Band PALSAR polarimetric SAR data were combined for vegetation cover mapping using ordinary least square (OLS) linear regression for fractional vegetation [16]. Sandholt [17] used a combination of polarimetric airborne SAR with satellite SAR and optical data for classification of agricultural land. This author used multi-spectral SPOT imagery, airborne polarimetric SAR data, and satellite-borne C-band SAR data to carry out the classification. Traditional maximum likelihood (MXL) classification was compared with classification incorporating a Gaussian mixture class model, and an algorithm based on multi-resolution structured data and sequential MAP (SMAP). High classification accuracies were obtained by using combinations of sensors. Cloude and Pottier [18] proposed an unsupervised algorithm of full polarimetric SAR data and feature vectors identification using radar target decomposition theorems and entropy analysis. They proposed that entropy arises as a natural measure of the inherent reversibility of the scattering data. Ianninia et al. [19] proposed an integration of multispectral and C-band SAR data for crop classification in the Indian Head (Canada) test site, using AgriSAR 2009 dataset, which comprised of multi-angle C-Band Radarsat-2 fine Quad-Pol images, RapidEye acquisitions, and extensive ground-truth for training and validation. The SAR image series was collected during the most significant part of the crop season for a wide range of ascending and descending modes. Crop classification was performed per-field by means of a convenient quasi-ML approach [19].

Betbeder et al. [20] used a multitemporal classification of TerraSAR-X data for wetland vegetation mapping. Authors evaluated the capability of multitemporal dual-pol TerraSAR-X images to accurately and precisely map the distribution of vegetation formations in wetland areas. For that purpose, the authors first extracted several parameters which vary with the wetland flooding status from the TerraSAR-X images. Researchers have applied different multitemporal classification techniques to the radar time series. Zhou et al. Used a parametric spatial classification of SAR images based on the fusion of multiple classifiers [21], while Haldar et al. carried out an assessment of ALOS-PALSAR L-band SAR data at different polarization combinations for crop and other land use classification [22]. They compared classification of HH polarization data with single-date dual, quad and hybrid-dual polarimetric modes, and finally classification accuracies were compared with ground reference measurements for Rabi crops and few associated land use classes. Others carried out a supervised classification of polarimetric SAR imagery using temporal and contextual information; they used the supervised contextual classification method based on the modeling using MRFs and Bayesian approach [23]. These researchers proposed a context-based algorithm using Gaussian-based Wishart distribution of PolSAR images. For modeling contextual information by Markove Random Field (MRF), an isotropic model with a second-order neighborhood system, and to find the maximum posterior probability (minimum energy function), and the iterated conditional modes (ICM) method was used.

\section{Classifiers Used in SAR Data}

Various methods were used for classification of polarimetric SAR data during the past years, such as the ones based on the MXL, artificial neural networks (ANN), support vector machines (SVM), fuzzy methods and other approaches (Table 2). Terrain classification using polarimetric SAR images is an active research field where several features and classifiers have been proposed to date. A collective network of (evolutionary) binary classifier (CNBC) framework has been used to achieve high classification outcomes. Both visual and numerical performance evaluations demonstrated the superiority of proposed CNBC framework against several major classifiers 
Table 2. Classification SAR images for information extraction.

\begin{tabular}{|c|c|c|c|}
\hline Satellite used & Study region & Classification & Result \\
\hline $\begin{array}{l}\text { TerraSAR-X } \\
{[20]}\end{array}$ & $\begin{array}{l}\text { Pleine Fougères, Bay of } \\
\text { Mont-Saint-Michel, Franc }\end{array}$ & $\begin{array}{l}\text { Different multitemporal } \\
\text { classification techniques }\end{array}$ & $\begin{array}{l}\text { Use of multitemporal TerraSAR-X images for } \\
\text { herbaceous wetland mapping and vegetation } \\
\text { formations is found to be very accurate }\end{array}$ \\
\hline $\begin{array}{l}\text { PALSAR and } \\
\text { LANDSAT [27] }\end{array}$ & $\begin{array}{l}\text { Eastern } \\
\text { Massachusetts }\end{array}$ & Random Forest classifier & $\begin{array}{l}\text { Combination of LANDSAT and PALSAR data } \\
\text { gives the best classification results for land cover } \\
\text { classification }\end{array}$ \\
\hline $\begin{array}{l}\text { Radarsat-2, } \\
\text { AgriSAR and } \\
\text { RapidEye [19] }\end{array}$ & $\begin{array}{l}\text { Indian Head (Canada) } \\
\text { agricultural site area }\end{array}$ & $\begin{array}{l}\text { Maximum Likelihood (MXL) } \\
\text { as supervised method }\end{array}$ & $\begin{array}{l}\text { multi-source data can deliver within land-cover, } \\
\text { and more specifically crop type, mapping } \\
\text { application }\end{array}$ \\
\hline $\begin{array}{l}\text { AIRSAR } \\
\text { Airborne } \\
\text { data }[28]\end{array}$ & $\begin{array}{l}\text { French Polynesia islands } \\
\text { located at the middle of } \\
\text { the South Pacific Ocean }\end{array}$ & $\begin{array}{l}\text { SVM (Support Vector } \\
\text { Machine) }\end{array}$ & $\begin{array}{l}\text { SVM for polarimetric SAR classification was } \\
\text { found to be relevant for land use cartography }\end{array}$ \\
\hline $\begin{array}{l}\text { PALSAR } \\
\text { Image [29] }\end{array}$ & $\begin{array}{l}\text { Roorkee, Laksar, Bijnor } \\
\text { regions, Uttarkhand, India }\end{array}$ & $\begin{array}{l}\text { Decision Tree classifier } \\
\text { and supervised classifiers }\end{array}$ & $\begin{array}{l}\text { The decision tree classifier recognizes all land } \\
\text { cover types more accurately from training pixels } \\
\text { than parallelepiped, minimum distance, MXL and } \\
\text { Wishart classifiers }\end{array}$ \\
\hline $\begin{array}{l}\text { TerraSAR-X } \\
{[30]}\end{array}$ & $\begin{array}{l}\text { Foshan in central } \\
\text { Guangdong province, } \\
\text { China }\end{array}$ & $\begin{array}{l}\text { Supervised hierarchical } \\
\text { Markov aspect models } \\
\text { (HMAM) }\end{array}$ & $\begin{array}{l}\text { TerraSAR-X SAR terrain map with pixel-level } \\
\text { ground truth show that HMAM is both accurate } \\
\text { and efficient, providing significantly better results } \\
\text { than comparable single-scale aspect models with } \\
\text { only a modest increase in training. }\end{array}$ \\
\hline $\begin{array}{l}\text { Radarsat-1 } \\
\text { SAR } \\
\text { image [31] }\end{array}$ & $\begin{array}{l}\text { Jeollabuk-do area } \\
\text { in Korea }\end{array}$ & Object-based classification & $\begin{array}{l}\text { SAR amplitude imagery and terrain information } \\
\text { by object-based classification is accurate and } \\
\text { significantly improved }\end{array}$ \\
\hline
\end{tabular}

in this field [24]. Neural networks are mostly used in pattern classification since information about the probability distribution and probabilities of deferent classes are not necessary. A two-hidden-layer back-propagation neural network has been adopted with sigmoid neurons in the hidden layers and linear neuron in the output layer. The training vectors are formed from the selected areas and normalized and presented to the NN which is trained in batch mode [25]. Parallelepiped classification employs a simple decision rule to carry out the classification of SAR images, in which the decision limits from an n-dimensional parallelepiped classification in the image data space. In this case, the dimensions are statistically defined based on a standard deviation threshold from the mean of each selected class [26]. The ISODATA (Iterative Self-Organizing Data Analysis Technique) classification method uses an iterative method that includes a number of general strategic procedures to compute classes. The ISODATA classification method is similar to the K-Means method but includes measures for spreading and combining the trial classes to achieve an optimal set of output classes. In ISODATA classifier, the user assigns the number of classes and it classifies according to the user-defined classes [26].

\section{Applications of Polarimetric SAR to Cryosphere}

The cryosphere is the frozen water region of the Earth, and it may be found in different categories, including snow cover, freshwater ice, sea ice, permafrost, and continental ice masses such as glaciers and ice sheets [32]. The cryosphere lowers the Earth's surface temperature by reflecting a large amount of sunlight, stores fresh water for millions of people, and provides habitat for many plants and animals. The cryosphere has a significant influence on global climate and human livelihoods. Variation in spatial and temporal distribution of the cryosphere influences the water flow in the world's major rivers [33]. Sea ice is frozen water characterized by a sheet of ice of varying thickness floating on the surface of the ocean. It is constantly changing due to melting, freezing, ocean currents and wind. Even though sea ice occurs in some of the most remote regions of the Earth, it has a great impact on the climate. Its high albedo causes much of the sunlight that hits its surface to be reflected back into space. The reflected solar energy helps keep the polar region cool. So detecting sea ice and obtaining a nearreal status is very essential. In order to detect sea ice, an automated computer-aided classification system is required. SAR has been widely employed for sea ice monitoring in polar regions. A computer-aided analysis of SAR sea ice imagery is extremely difficult due to several imaging parameters and environmental factors. New 
technologies have recently been applied to satellite-borne sea-ice RS, including SAR, scatterometry, and altimetry. SAR provides detailed images of the ice cover at spatial resolutions as high as $30 \mathrm{~m}$. The advent of SAR radically changed the capabilities of the operational centers, allowing much higher quality analysis, including information on lead location/orientation, ice type, new ice formation, and ice thickness. SAR instruments on ERS-1/2, Radarsat, Envisat, and Advanced Land Observing Satellite (ALOS) provide useful high-resolution information on deformation, leads, ridging, and new ice production. All these parameters are needed to understand the increasing of the ice cover around Antarctica. SAR provides the best high-resolution data from space and is extremely important for operational support. In spite of what preceded, there are significant ambiguities in the single polarization backscatter signature, making interpretation difficult at times. Less downloading facilities in the polar regions have limited the amount of data available, particularly in the Antarctic. SAR can be used to map ice cover and areas of open water on rivers and lakes, and to identify areas of floating and grounded ice. Scheuchl et al. [34] reviewed SAR measurement for sea ice parameters. In this overview paper, the authors have summarized both the operational and climate change research by using SAR for sea ice parameter detection (Table 3). There are uncertainties with respect to the extraction of SAR derived sea ice parameters. An empirical model has been developed to estimate snow density from SAR backscattering. In the absence of free water and ice layers in the snowpack, the microwave scattering and emission behavior are governed by the snowpack depth and its density. The complexity in the behavior of snow density to the total radar backscattering makes it difficult to develop a model for estimating snow density from single polarization C-band SAR data. Therefore, an empirical model has been adopted. The total backscattering has been considered as a third-order polynomial of snow density. In the microwave region, active SAR sensors are used to map dry and wet snow. Passive microwave sensors such as Special Sensor Microwave Imager (SSM/I) help in the determination of the thickness of snow and ice [35].

Multitemporal SAR images are very useful sources of information for a lot of applications, especially for change detection and monitoring, and crevasses detection for the safe movement of the convoy in polar regions. A crevasse is a fracture in a glacier caused due to large tensile stresses at or nearby the glacier surface. Crevasse detection is necessary for the safety of the field campaigns in the expedition. Radar is a useful method for ice crevasse detection, which has been used in Antarctica since 1975. Earlier, radar crevasse detection systems could not sense a crevasse until the vehicle or sensor was directly above it. Accordingly, airborne radar was used for ice crevasse detection in the Antarctic expeditions. Compared with optical satellite image, SAR image can detect crevasse under the snow bridge because radar can penetrate the snow surface. Crevasse detection also provides information to monitor dynamic changes of the ice sheet. Crevasses can be detected using SAR images by manual interpretation or filter group based on the linear discontinuity. Semi-variance function can be adapted for crevasse detection in SAR images, based on the directional characteristic of crevasse texture.

\section{Applications of Interferometric SAR (InSAR) to Cryosphere}

The distribution of blue ice can be studied from the SAR images. In SAR satellite image, blue ice can also be visually recognized. The amplitude of the signal of blue ice is lower than that of snow, because the ice surface is smoother than the latter. But the difference is not so obvious when automatic extraction techniques are applied. Blue ice can be recognized easily in the coherence map derived from two SAR images, because of the higher coherence of blue ice one can differentiate it from snow and mountain areas. Application of SAR interferometric coherence to discriminate the target blue ice is studied over polar inland ice. Interferometric coherence analysis

\begin{tabular}{|c|c|}
\hline Satellite & SAR Operations over Sea Ice \\
\hline Radarsat-1 [34] [36] [37] & Operational sea ice monitoring \\
\hline Radarsat SAR [38] & Automated ice edge algorithm for location \\
\hline Envisat ASAR and Radarsat-1 [39] & Sea ice drift monitoring \\
\hline Radarsat-1 and-2 [40] & Sea ice thickness and concentration analysis \\
\hline Sentinel-1 [41] & Sea ice melt pond fraction estimation \\
\hline Radarsat Geophysical Processor System (RGPS) [42] & Sea ice deformation \\
\hline
\end{tabular}


is carried out in the Grove Mountains region in East Antarctica, using a pair of tandem ERS-1/2. The study indicates considerable variations in coherence between blue ice and other ice sheet features, suggesting possibilities for blue ice discrimination. The generated blue ice target map was compared to a reference blue ice map extracted from Landsat thematic mapper (TM) image, which indicate good consistency for target discrimination [43]. SAR interferometry (InSAR) has proved to be useful in the application of generating the digital elevation model (DEM), topographic mapping and surface detection in the areas which are out of reach, such as Grove Mountains, east Antarctica [43].

An improved understanding of ice sheet dynamics is essential to determine the mass balance of ice sheets and their contributions to sea level [44] [45]. Measurements of temperate glacier velocities and surface characteristics by airborne and space-borne interferometric satellite images have been of the significant application in glaciology and cryospheric studies. DEM generation and velocity mapping are the two most important applications to cryosphere using SAR interferometry. InSAR is capable of measuring ice motion and has radically changed the science of glaciers and ice sheets [46]. InSAR techniques are useful in generating DEM of glaciers. Time difference DEMs have been used to infer velocity of ice and mass balance of glaciers. Glacier velocity is also an important control factor of the ice discharge rate of calving glaciers. Study of ice velocity field is one of the key issues for understanding glacier dynamics. Surface velocity fields can provide useful information on phenomena such as glacier surges or ice fall. Although the surface displacements of glaciers can be monitored in-situ with ground GPS points, this solution is hardly possible in terms of both implementation and cost. Glaciers displacements can be accurately measured using interferometry. Jawak and Luis [47] used multitemporal RAMP, ICESat and GPS data to construct an accurate DEM of the Larsemann hills and Schirmacher oasis region, east Antarctica [47]-[50]. In another attempt, Jawak and Luis [51] merged the photogrammetric Cartosat-1 DEM and RAMP elevation data to generate improved DEM of Schirmacher Oasis, east Antarctica. Joughin et al. [52] reviewed glaciological advances made with InSAR. Spaceborne InSAR techniques for measuring ice flow velocity and topography have developed rapidly over the last decade. Spaceborne InSAR has contributed to major advances in many research fields of glaciological study by providing measurements of ice-stream flow velocity, improving understanding of several ice-sheet and ice-shelf processes, yielding velocity for flux-gate based massbalance assessment, mapping flow of mountain glaciers, and capturing the geomorphic traces of past ice flow. Joughin et al. [52] reviewed the basic method development, the measurement characteristics, and the extensive set of results yielded by InSAR measurements. Rignot et al. [44] estimated the recent Antarctic ice mass loss by using radar interferometry and regional climate modeling. Rignot [53] detected hinge-line migration on Rutford Ice Stream and Carlson Inlet, Antarctica using radar interferometry. Jezek [54] studied the glaciological properties of the Antarctic ice sheet from Radarsat-1 SAR imagery. In other studies, researchers presented Radarsat 1 SAR observations of Antarctica under modified Antarctic mapping mission [55]. Michel and Rignot [56] estimated the flow of Glacier Moreno, Argentina, from repeat-pass shuttle imaging radar images and carried out a comparison of the phase correlation method with radar interferometry. Bamber et al. [57] developed a new $1 \mathrm{~km}$ DEM of the Antarctica by combining satellite radar and laser data. Hoen and Zebker [58] studied the penetration depths inferred from interferometric volume decorrelation observed over the Greenland Ice Sheet. Rignot et al. [29] demonstrated the penetration depth of interferometric SAR signals in snow and ice. Rignot et al. [60] presented a reference, comprehensive, high-resolution, digital mosaic of ice motion in Antarctica assembled from multiple satellites InSAR data acquired during the International Polar Year 2007-2009. The data revealed widespread, patterned, enhanced flow with tributary glaciers reaching hundreds to thousands of kilometers inland over the entire continent. Joughin et al. [61] demonstrated the interferometric estimation of three-dimensional ice-flow using ascending and descending passes. The authors have developed and demonstrated a technique that allows the three-component velocity vector to be estimated from data acquired along two track directions (ascending and descending) under a surface parallel flow assumption for the Ryder Glacier, Greenland. Joughin [62] proposed a combined interferometric and speckle-tracking approach for ice-sheet velocity mapping. Griggs and Bamber [63] presented validation and error estimates for a new $1 \mathrm{~km}$ DEM of Antarctica derived from combined radar and laser data. Rignot et al. [13] used differential satellite radar interferometry for Antarctic grounding line mapping. Table 4 summarizes the applications of InSAR in cryosphere.

\section{Summary and Discussion}

SAR is an airborne or space-borne SLR system which generates high-resolution RS imagery. Various methods 
Table 4. InSAR applications in cryosphere.

\begin{tabular}{|c|c|c|}
\hline Satellite used & Study region & Application \\
\hline CryoSat-2 [64] & $\begin{array}{l}\text { Antarctic Peninsula, West Antarctica, East } \\
\text { Antarctica and Greenland }\end{array}$ & $\begin{array}{l}\text { Determining elevation and elevation change } \\
\text { of Greenland and Antarctica }\end{array}$ \\
\hline TerraSAR-X [65] & $\begin{array}{l}\text { Eastern shoreline of Hudson Bay in Nunavik, } \\
\text { Canada in the transition zone between the } \\
\text { sub-Arctic and the Arctic }\end{array}$ & $\begin{array}{l}\text { Detection of vertical surface movements of frost } \\
\text { mounds in sub-Arctic permafrost regions }\end{array}$ \\
\hline ENVISAT and CryoSat [66] & Fram Strait, between Greenland and Svalbard & $\begin{array}{l}\text { Development of SAR altimetry mode studies and } \\
\text { applications over ocean, coastal zones and inland water }\end{array}$ \\
\hline ERS-1 and ERS-2 [43] & $\begin{array}{l}\text { Grove mountains area located to the southwest } \\
\text { of princess Elizabeth land, inland areas of east } \\
\text { Antarctica }\end{array}$ & $\begin{array}{l}\text { Potential technique for DEM generation, topographic } \\
\text { mapping, and surface motion detection in the } \\
\text { inaccessible areas }\end{array}$ \\
\hline $\begin{array}{l}\text { ERS } 1 \& 2 \text { SAR and } \\
\text { ENVISAT ASAR [67] }\end{array}$ & $\begin{array}{l}\text { Gangotri and Siachen glaciers located in } \\
\text { Uttaranchal and Jammu and Kashmir state } \\
\text { of India }\end{array}$ & $\begin{array}{l}\text { Potential technique for DEM generation and glacier } \\
\text { movemen of two major Himalayan glaciers in India }\end{array}$ \\
\hline TerraSAR-X [68] & Eurasian Arctic; Austfonna, eastern Svalbard & $\begin{array}{l}\text { Importance of dynamic ice-mass loss for glacier } \\
\text { mass balance. }\end{array}$ \\
\hline
\end{tabular}

for fractional snow-covered area evaluation have been designed for different geographical regions. The backscatter response of microwave energy is a complex blend of a variety of influences such as surface roughness, dielectric constant, penetration depth, subsurface features, presence of liquid water, frequency, viewing geometry (incident and azimuth angles), surface slopes, etc. Polarimetric SAR data have a challenging task because of the complexity of measured information from its multiple polarimetric channels. Over the past decade, there has been substantial research in the area of the segmentation and classification of polarimetric SAR data Polarimetric SAR classification can be based on either supervised or unsupervised methods, their accuracy and suitability mainly depend on applications and the availability of ground truth. Interpretation of the classified results can become a complicated task, especially as the surface target becomes more complex. Thus, the accuracy of classification is uncertain. For example, in the case of mapping snow cover, differentiating the contributions from vegetation, snow, and the underlying soil is not practically feasible using only a single frequency scatterometers. SAR images of sea ice illustrate considerable variability in appearance as a function of imaging conditions (polarization, incidence angle, frequency, etc.), sea ice conditions (surface roughness, ice type etc.), and meteorological conditions during SAR acquisition. Therefore, there should be a consistent improvement of understanding of SAR imaging of sea ice by investigating the relationship of radiometric, statistical and polarimetric signal properties to physical properties of sea ice surface. The ultimate aim of the study of the cryospheric region is to enable robust and consistent classification of sea ice from SAR data with relatively good accuracy. Such a classification technique would be important for both operational sea ice monitoring services and climate change researchers.

DEM is extensively used to detect the temporal changes of glacial lakes, glaciers, and moraines by comparing two DEMs produced at two different time intervals. Most of the glacial lake outburst flood happens during the rainy season and, therefore, monitoring the glaciers is a very difficult task due to bad weather circumstances and presence of dense clouds. Over the past decades, space-borne InSAR has revolutionized our ability to detect the surface motion of glaciers and ice sheets (e.g., [52]). This technique enables large-scale measurements of ice motion, day and night, independent of cloud cover (e.g., [53]), at a wide spatial resolution. InSAR coverage of Antarctica initiated in 1991 with the launch of the ERS-1 in tandem with ERS-2. In 1997, Radarsat-1 imaged regions south of $81^{\circ} \mathrm{S}$ interferometrically for the first time, including South Pole, after the satellite was rotated to point its radar antenna to the south [54]. In 2000, RAMP acquired data north of $80.1^{\circ} \mathrm{S}$ repeatedly and interferometrically [55], but the data proved difficult to use in northern West Antarctica, the Antarctic Peninsula and Wilkes Land in East Antarctica, due to high temporal decorrelation of the radar signal.

SAR can be labeled as the investigative tool, for snow mapping in cryospheric regions. The sensitivity of radar wavelengths to surface roughness and moisture content of snow suggest that SAR is a potentially ideal RS tool for detecting rapidly changing conditions on the Earth's surface occurring at any weather situation or time of the day. For example, ERS-1 offers a unique possibility to map the collapse of an ice shelf at the time scale of a few days. Another application area is the detection of changes in the ice margin and nearby lakes and the map- 
ping of snow facies boundaries on the Greenland ice sheet. Glacier mass balance can be estimated using C-band SAR data. One of the major obstacles in analyzing SAR images for finding changes in backscattering is the strong reliance of the image characteristics on the imaging geometry, especially in mountainous terrain with a large influence of the topography. For many applications which are based on analysis of the radar cross section of distributed targets, speckle is an unwanted feature. In the microwave region, it is hardly possible to discriminate between firn and snow. For many applications in RS such as multi-temporal investigations or combinations of data from diverse sensors and also for contrast with ground-based observations, it is essential to transform all the data to the same coordinate system or map projection. On the other hand, images generated by SAR are generally distributed in slant range or ground range geometry. In rugged terrain, a SAR image in this projection shows topographically induced distortions, shadow and layover areas. Another difficulty is that smaller water bodies are difficult to map with SAR.

Satellite RS of the cryosphere has progressed over the last five decades. It has helped us to understand the global distribution of the cryosphere, changes and trends in snow cover, sea ice, and glaciers. SAR has helped in the rapid assessment of glaciers in areas such as Antarctica, the Arctic, and alpine glacier. For the Greenland and Antarctic ice sheets, satellite-based altimeters and SARs are providing deep introspection into ice topography and the velocities at which the ice flows to the sea. Recent studies have proven the potential nature of the SAR technique which is evolving day-by-day with new creative ideas for the cryospheric regions. SAR data have been proven potentially superior in cryospheric regions. Still, there is some lacuna in present studies which can be revisited in future. Crevasse detection under the snow \& use of SAR in the mountainous region still remains challenging tasks, for which solution can be developed in future.

\section{Future Directions}

SAR technology can effectively extract the ice sheet surface information and can measure the surface topography of polar regions. SAR technology can be effectively used in snow and ice classification, accumulation rate estimation, grounding line identification, studying glacier dynamics, ice shelf tidal movement, sea ice monitoring, subglacial lake exploration, etc. [69]. Nowadays, SAR systems have higher spatial resolution and more operating polarizations. Especially during the polar night, SAR satellites can provide regular RS data. These advantages make SAR technology become one of the most vital means for cryospheric studies [69]. It provides important scientific and technical support for the polar research, and for studying dynamic changes of ice sheets, ice shelves, glaciers and sea ice, etc. SAR images can be used for mapping, surface classification (dry snow and wet snow classification), target feature extraction including blue ice and crevasse, temporal and spatial changes of ice shelves, sea ice monitoring and classification and ice velocity mapping based on feature tracking, etc. InSAR can be used to generate DEM of the Antarctic ice sheet and, extract blue ice and crevasse based on coherence information, etc. [69]. Moreover, accurate ice velocity mapping, extraction and change monitoring of grounding line, etc., can be achieved using DInSAR methods. Moreover, InSAR, DInSAR and speckle tracking technology are highly capable to measure glacier surface displacements with high precision. In order to provide a special emphasis on the applications of SAR in Antarctica, polarimetric SAR, InSAR, and DInSAR were surveyed in this paper. In addition to these well-known methods, there are a few very recent methods developed in SAR technology, which can be used in future for improved polar research, such as, persistent scatterer Interferometric SAR (PSInSAR), SAR tomography (TomoSAR), and polarimetric InSAR (PolInSAR). In case of crevasse detection, it is necessary to design new methods based on texture and context characteristics to reduce false detection. In case of ice velocity mapping, the accuracy should be improved by detecting the seasonal and annual changes of ice velocity. Additionally, the phase errors induced by atmosphere should be corrected [69].

\section{Conclusion}

SAR is an ideal RS technology, which works in all-weather and day and night situations in the remote cryospheric regions on Earth, and gives the useful unprecedented spatial information. We reviewed about the evolving nature of SAR in the cryosphere, and highlighted various components of the cryosphere and the classification and applications of SAR in the cryospheric studies. SAR technology is very effective to monitor changes of ice sheets, ice shelves, glaciers, sea ice, snow, blue ice, etc. to study the relationship between polar regions and global climate change. We have reviewed a wide variety of applications of SAR technology, which include a study of ice sheet surface features based on SAR images and coherence, DEM generation with InSAR, and sur- 
face deformation monitoring using DInSAR and speckle tracking methods. The cryosphere research aims to develop the understanding of the processes and dynamics of various parts of the cryosphere, namely land ice, ice shelves, glaciers, snow, sea ice, and permafrost. The combination of microwave RS, field surveys and modeling is the main approach to address this research topic. Besides operational monitoring, the quantitative evaluation of essential variables from SAR systems allows improving the understanding of processes and systems. There are several challenges in RS of the cryosphere. The development of operational methods primarily based on the use of high-resolution SAR imagery is needed. Synergetic usage of SAR systems can greatly improve the knowledge of the dynamics and stability of various components in the cryosphere. Changes in glaciers provide evidence of climate change, and therefore glaciers play a key role in early detection of global climate-related observations. Glacier change will impact global sea level and other natural hazards. These environmental changes demand international glacier monitoring efforts to prioritize the use of SAR data in conjunction with traditional field observations.

\section{Acknowledgements}

We acknowledge Dr. S. Rajan, Director, NCAOR for his encouragement and motivation of this research. We acknowledge Dr. T. P. Singh (Director, SIT), Dr. Kanchan Khare (HOD, Department of Civil Engineering, SIT), Prof. Sagar Kolekar (SIT), and Prof. Rajesh Kherde(SIT), for their cooperation. We also thank Ms. Prachi Vaidya, India for her constructive comments on the draft version of the manuscript. This is NCAOR contribution No. $18 / 2015$.

\section{References}

[1] SAR. http://ethw.org/Synthetic_Aperture_Radar

[2] Aher, S.P., Khemnar, S.B. and Shinde, S.D. (2014) Synthetic Aperture Radar in Indian Remote Sensing. International Journal of Applied Information Systems (IJAIS), 7, 41-44. http://www.researchgate.net/profile/Sambhaji_Shinde/publication/264973567_Synthetic_Aperture_Radar_in_Indian_R emote_Sensing/links/53f8861e0cf2823e5bdbe5b3.pdf

[3] Chakraborty, M., Panigrahy, S., Rajawat, A.S., Kumar, R., Murthy, T.V.R., Haldar, D., Chakraborty, A., Kumar, T., Rode, S., Kumar, H., Mahapatra, M. and Kundu, S. (2013) Initial Results Using RISAT-1 C-Band SAR Data. Current Science, 104, 490-501. http://www.currentscience.ac.in/Volumes/104/04/0490.pdf

[4] Ersahin, K., Cumming, I. and Yedlin, M. (2006) Classification of Polarimetric SAR Data Using Spectral Graph Partitioning. IEEE International Symposium on Geosciences and Remote Sensing, Denver, 31 July-4 August 2006, 17561759. http://dx.doi.org/10.1109/igarss.2006.454

[5] Sandven, S., Johannessen, M. and Kloster, K. (2006) Sea Ice Monitoring by Remote Sensing. http://www.researchgate.net/profile/Ola_Johannessen/publication/227992512_Sea_Ice_Monitoring_by_Remote_Sensi ng/links/00b4953721f47dfcf3000000.pdf

[6] Wesche, C., Jansen, D. and Dierking, W. (2013) Calving Fronts of Antarctica: Mapping and Classification. Remote Sensing, 5, 6305-6322. http://dx.doi.org/10.3390/rs5126305

[7] Jezek, K., Sohn, H. and Noltimier, K. (1998) The Radarsat Antarctic Mapping Project. Proceedings of 1998 IEEE Geoscience and Remote Sensing Symposium Proceedings, 5, 2462-2464. http://dx.doi.org/10.1109/igarss.1998.702246

[8] Septhon, A., Brown, L., Macklin, J.T., Partington, K.C., Veck, N. and Rees, W. (1994) Segmentation of Synthetic-Aperture Radar Imagery of Sea Ice. International Journal of Remote Sensing, 15, 803-825. http://www.tandfonline.com/doi/pdf/10.1080/01431169408954118

[9] Young, N.W., Turner, D., Hyland, G. and Williams, R.N. (1998) Near-Coastal Iceberg Distribution in East Antarctica. Annals of Glaciology, 27, 68-74.

http://www.researchgate.net/publication/253069207 Near coastal iceberg distributions in East Antarctica 50E - 1 $\underline{45 \mathrm{E}}$

[10] Wesche, C. and Dierking, W. (2012) Iceberg Signatures and Detection in SAR Images in Two Test Regions of the Weddell Sea, Antarctica. J. Glaciol., 58, 325-339. http://dx.doi.org/10.3189/2012J0G11J020

[11] Willis, C.J., Macklin, J.T., Partington, K.C., Teleki, K.A., Rees, W.G. and Williams, R.G. (1996) Iceberg Detection Using ERS-1 Synthetic Aperture Radar. International Journal of Remote Sensing, 17, 1777-1795. http://dx.doi.org/10.1080/01431169608948739

[12] Mouginot, J., Scheuchl, B. and Rignot, E. (2012) Mapping of Ice Motion in Antarctica Using Synthetic Aperture Radar Data. Remote Sensing, 4, 2753-2767. http://dx.doi.org/10.3390/rs4092753 
[13] Rignot, E., Mouginot, J. and Scheuchl, B. (2011) Measures InSAR-Based Antarctica Ice Velocity Map. National Snow and Ice Data Center, Boulder.

[14] Fricker, H.A., Young, N.W., Allison, I. and Coleman, R. (2002) Iceberg Calving from the Amery Ice Shelf, East Antarctica. Annals of Glaciology, 34, 241-246. http://dx.doi.org/10.3189/172756402781817581

[15] Jawak, S.D. and Luis, A.J. (2014) Prospective Application of NASA-ISRO SAR (NISAR) in Cryospheric Studies: A Practical Approach. NISAR Science Workshop, Space Applications Centre (SAC), Ahmadabad, 17-18 November 2014. http://www.researchgate.net/publication/268503242_Prospective_application_of_NASA-ISRO_SAR_(NISAR) in_cry ospheric studies_a practical approach

[16] Maitra, S. (2013) Analysis of Polarimetric Synthetic Aperture Radar and Passive Visible Light Polarimetric Imaging Data Fusion for Remote Sensing Applications. PhD Thesis, Rochester Institute of Technology, New York. http://scholarworks.rit.edu/cgi/viewcontent.cgi?article=1939\&context=theses

[17] Sandholt, I. (2001) Combination of Polarimetric SAR with Satellite SAR and Optical Data for Classification of Agricultural Land. Geografisk Tidsskrift-Danish Journal of Geography, 101, 21-32. http://dx.doi.org/10.1080/00167223.2001.10649448

[18] Pottier, E. and Cloude, S.R. (1995) Unsupervised Classification of Full Polarimetric SAR Data and Feature Vectors Identificat1on Using Radar Target Decomposition Theorems and Entropy Analysis. Conference Paper Published for International Geosciences and Remote Sensing Symposium, Vol. 3, Firenze, 2247-2249.

[19] Ianninia, L., Molijna, R.A. and Hanssena, R.F. (2014) Integration of Multispectral and C-Band SAR Data for Crop Classification. Proceedings of SPIE, Remote Sensing for Agriculture, Ecosystems, and Hydrology XV, 8887, Article ID: 88871D. http://dx.doi.org/10.1117/12.2029330

[20] Betbeder, J., Rapinel, S., Corpetti, T., Pottier, E., Corgne, S. and Hubert-Moy, L. (2014) Multitemporal Classification of TerraSAR-X Data for Wetland Vegetation Mapping. Remote Sensing, 8, Article ID: 083648. http://dx.doi.org/10.1117/1.jrs.8.083648

[21] Ma, X.S., Yang, H.S.G., Zhang, L. and Li, P. (2014) Polarimetric-Spatial Classification of SAR Images Based on the Fusion of Multiple Classifiers. Remote Sensing, 7, 961-971. http://dx.doi.org/10.1109/jstars.2013.2265331

[22] Haldar, D., Das, A., Mohan, S., Pal, O., Hooda, R.S. and Chakraborty, M. (2012) Assessment of L-Band SAR Data at Different Polarization Combinations for Crop and Other Land Use Classification. Electromagnetics Research B, 36, 303-321. http://dx.doi.org/10.2528/PIERB11071106

[23] Dargahi, A., Maghsoudi, Y. and Abkar, A.A. (2013) Supervised Classification of Polarimetric SAR Imagery Using Temporal and Contextual Information. Remote Sensing and Spatial Information Sciences, XL-1/W3, 107-110. http://dx.doi.org/10.5194/isprsarchives-xl-1-w3-107-2013

[24] Kiranyaz, S., Uhlmann, S. and Gabbouj, M. (2011) Polarimetric SAR Images Classification using Collective Network of Binary Classifiers. Conference Paper published in Urban Remote Sensing Event, Munich, 11-13 April 2011, 245248.

[25] Zhang, Y.D., Wu, L.N. and Wei, G. (2009) A New Classifier for Polarimetric SAR Images. Electromagnetics Research, 94, 83-104. http://dx.doi.org/10.2528/PIER09041905

[26] Vanitha, A., Subashini, P. and Krishnaveni, M. (2013) SAR Ice Image Classification Using Parallelepiped Classifier Based On Gram-Schmidt Spectral Technique. Conference Paper Published in Computer Science \& Information Technology (CS \& IT), Coimbatore, 385-392.

[27] Rogan, J., Zhu, Z., Woodcock, C.E. and Kellndorfer, J. (2012) Assessment of Spectral, Polarimetric, Temporal, and Spatial Dimensions for Urban and Peri-Urban Land Cover Classification Using Landsat and SAR Data. Remote Sensing, 117, 72-82. http://dx.doi.org/10.1016/j.rse.2011.07.020

[28] Frison, P.L., Lardeux, C., Rudant, J.P., Souyris, J.C., Tison, C. and Stoll, B. (2006) Use of the SVM Classification with Polarimetric SAR Data for Land Use Cartography. Conference Paper Published in Geoscience and Remote Sensing Symposium, Denver, 31 July-4 August 2006, 493-496.

[29] Mishra, P., Singh, D. and Yamaguchi, Y. (2011) Land Cover Classification of Palsar Images by Knowledge Based Decision Tree Classifier and Supervised Classifiers Based On SAR Observables. Electromagnetic Research B, 30, 47-70. http://dx.doi.org/10.2528/PIERB11011405

[30] Yang, W., Dai, D., Triggs, B. and Xia, G. (2012) SAR-Based Terrain Classification Using Weakly Supervised Hierarchical Markov Aspect Models. IEEE Transactions on Image Processing, 21, 4232-4243. http://dx.doi.org/10.1109/TIP.2012.2199127

[31] Hong, S., Jang, H., Kim, N. and Sohn, H. (2015) Water Area Extraction Using RADARSAT SAR Imagery Combined with Landsat Imagery and Terrain Information. Sensors, 15, 6652-6667. http://dx.doi.org/10.3390/s150306652

[32] NSIDC. http://nsidc.org/arcticseaicenews/2011/10 
[33] Ambinakudige, S. and Joshi, K. (2012) Remote Sensing of Cryosphere. In: Boris Escalante-Ramirez, Ed., Earth and Planetary Sciences, Geology and Geophysics, InTech. http://dx.doi.org/10.5772/35194

[34] Scheuchl, B., Flett, D.G., Caves, R. and Cumming, I. (2004) Potential of RADARSAT-2 Data for Operational Sea Ice Monitoring. Canadian Journal of Remote Sensing, 30, 448-461. http://dx.doi.org/10.5589/m04-011

[35] Kasturirangan, K., Navalgund, R.R. and Ajai (2013) Observed Changes in the Himalayan-Tibetan Glaciers. Fate of Mountain Glaciers in the Anthropocene Pontifical Academy of Sciences, Scripta Varia, 118. www.pas.va/content/dam/accademia/pdf/sv118/sv118-kasturirangan.pdf

[36] Pichel, W.G., Thompson, D.R. and Clemente-Colon, P. (2004) A Systematic Comparison of QuikSCAT and SAR Ocean Surface Wind Speeds. Remote Sensing, 42, 283-291. http://dx.doi.org/10.1109/TGRS.2003.817213

[37] Sandven, S., Kloster, K., Tangen, H., Andreassen, T., Goodwin, H. and Partington, K. (2004) Sea Ice Mapping Using Envisat Asar Wideswath Images. http://earth.esa.int/workshops/cmasar_2003/papers/E17sand.pdf

[38] Wackerman, C. and Johannessen, J. (2003) Operational Monitoring of Coastal and Marine Environment with Spaceborne Sar Systems: Where Are We Now and Where Are We Going. http://earth.esa.int/workshops/cmasar 2003/papers/E01wack.pdf

[39] Karvonen, J. (2012) Operational SAR-Based Sea Ice Drift Monitoring over the Baltic Sea. Ocean Science Discussions, 9, 359-384. http://dx.doi.org/10.5194/osd-9-359-2012

[40] Karvonen, J., Cheng, B., Vihma, T., Arkett, M. and Carrieres, T. (2012) A Method for Sea Ice Thickness and Concentration Analysis Based on SAR Data and a Thermodynamic Model. The Cryosphere, 6, 1507-1526. http://dx.doi.org/10.5194/tc-6-1507-2012

[41] Scharien, R.K., Landy, J. and Barber, D.G. (2014) Sea Ice Melt Pond Fraction Estimation from Dual-Polarisation C-Band SAR-Part 1: In Situ Observation. The Cryosphere, 8, 805-844. http://dx.doi.org/10.5194/tcd-8-805-2014

[42] Bouillon, S. and Rampal, P. (2015) On Producing Sea Ice Deformation Data Sets from SAR-Derived Sea Ice Motion. The Cryosphere, 6, 663-673. http://dx.doi.org/10.5194/tc-9-663-2015

[43] Dongchen, E., Zhou, C. and Liao, M. (2004) Application of SAR Interferometry on DEM Generation of the Grove Mountains. Photogrammetric Engineering \& Remote Sensing, 70, 1145-1149. http://dx.doi.org/10.14358/PERS.70.10.1145

[44] Rignot, E., Bamber, J.L., van den Broeke, M.R., Davis, C., Li, Y., van de Berg, W.J. and van Meijgaard, E. (2008) Recent Antarctic Ice Mass Loss from Radar Interferometry and Regional Climate Modelling. Nature Geoscience, 1, 106-110. http://dx.doi.org/10.1038/ngeo102

[45] Rignot, E., Velicogna, I., van den Broeke, M.R., Monaghan, A. and Lenaerts, J. (2011) Acceleration of the Contribution of the Greenland and Antarctic Ice Sheets to Sea Level Rise. Geophysical Research Letters, 38. http://dx.doi.org/10.1029/2011g1046583

[46] Cryosphere Theme Report. http://www.wgms.ch/downloads/IGOS 2007.pdf

[47] Jawak, S.D. and Luis, A.J. (2012) Synergistic Use of Multitemporal RAMP, ICESat and GPS to Construct an Accurate DEM of the Larsemann Hills Region, Antarctica. Journal of Advances in Space Research, 50, 457-470. http://dx.doi.org/10.1016/j.asr.2012.05.004

[48] Jawak, S.D., Sambhus, P.G, Paranjape, R.A. and Luis, A.J. (2012) Assessment of Spatial Interpolation Techniques for Generating Accurate Digital Elevation Surface Using Combined Radar \& LiDAR Elevation Data. Proceedings of 8th International Conference on Microwaves, Antenna Propagation and Remote Sensing (ICMARS), Jodhpur, 11-15 December 2012, 288-291. http://www.atree.org/sites/default/files/articles/ja_2012_1.pdf

[49] Jawak, S.D. and Luis, A.J. (2011) Synergetic Use of GLAS/ICESat and RAMP to Construct 3D DEM of Schirmacher Oasis, East Antarctica. 11th International Symposium on Antarctic Earth Sciences (ISAES), Edinburgh, 10-16 July 2011.

https://www.academia.edu/11885824/Synergetic use of GLAS ICESat and RAMP to construct 3D DEM of Sch irmacher_Oasis_East_Antarctica

[50] Jawak, S.D. and Luis, A.J. (2010) Synergistic Use of SAR, GLAS/ICESat \& Ground Survey (GPS) Data to Construct an Accurate DEM of the Larsemann Hills Region. 4th SCAR-OSC-2010, Buenos Aires, 3-6 August 2010. http://www.researchgate.net/publication/234162507 Synergistic use of SAR GLASICESat Ground Survey \%28G PS\%29 data to Construct an_accurate_DEM_of the Larsemann_Hills_Region

[51] Jawak, S.D. and Luis, A.J. (2014) Synergetic Merging of Cartosat-1 and RAMP to Generate Improved Digital Elevation Model of Schirmacher Oasis, East Antarctica. International Archives of the Photogrammetry, Remote Sensing and Spatial Information Sciences, XL-8, 517-524. http://dx.doi.org/10.5194/isprsarchives-XL-8-517-2014

[52] Joughin, I., Smith, B.E. and Abdalati, W. (2010) Glaciological Advances Made with Interferometric Synthetic Aperture Radar. Journal of Glaciology, 56, 1026-1042. http://dx.doi.org/10.3189/002214311796406158 
[53] Rignot, E. (1998) Radar Interferometry Detection of Hinge-Line Migration on Rutford Ice Stream and Carlson Inlet, Antarctica. Annals of Glaciology, 27, 25-32.

http://www.researchgate.net/profile/E_Rignot/publication/241446675_Radar_interferometry_detection_of hinge-line migration_on_Rutford_Ice_Stream_and_Carlson_Inlet_Antarctica/links/544f83040cf26dda089185cb.pdf

[54] Jezek, K.C. (1999) Glaciological Properties of the Antarctic Ice Sheet from Radarsat-1 Synthetic Aperture Radar Imagery. Annals of Glaciology, 29, 286-290. http://dx.doi.org/10.3189/172756499781820969

[55] Jezek, K.C., Farness, K., Carande, R., Wu, X. and Labelle-Hamer, N. (2003) Radarsat-1 Synthetic Aperture Radar Observations of Antarctica: Modified Antarctic Mapping Mission. Radio Science, 38.

[56] Michel, R. and Rignot, E. (1999) Flow of Glaciar Moreno, Argentina, from Repeat-Pass Shuttle Imaging Radar Images: Comparison of the Phase Correlation Method with Radar Interferometry. Journal of Glaciology, 45, 93-100. http://www.igsoc.org:8080/journal/45/149/igs_journal_vol45_issue149_pg93-100.pdf

[57] Bamber, J.L., Gomez-Dans, J.L. and Griggs, J.A. (2008) A New 1 km Digital Elevation Model of the Antarctic Derived from Combined Satellite Radar and Laser Data_Part 1: Data and Methods. The Cryosphere, 3, 101-111. http://dx.doi.org/10.5194/tc-3-101-2009

[58] Hoen, W.E. and Zebker, H. (2000) Penetration Depths Inferred from Interferometric Volume Decorrelation Observed over the Greenland Ice Sheet. IEEE Transactions on Geoscience and Remote Sensing, 38, 2571-2583. http://dx.doi.org/10.1109/36.885204

[59] Rignot, E., Echelmeyer, K. and Krabill, W. (2001) Penetration Depth of Interferometric Synthetic-Aperture Radar Signals in Snow and Ice. Geophysical Research Letters, 28, 3501-3504. http://dx.doi.org/10.1029/2000GL012484

[60] Rignot, E., Mouginot, J. and Scheuchl, B. (2011) Ice Flow of the Antarctic Ice Sheet. Science, 333, 1427-1430. http://dx.doi.org/10.1126/science.1208336

[61] Joughin, I.R., Kwok, R. and Fahnestock, M.A. (1998) Interferometric Estimation of Three-Dimensional Ice-Flow Using Ascending and Descending Passes. IEEE Transactions on Geoscience and Remote Sensing, 36, 25-37. http://dx.doi.org/10.1109/36.655315

[62] Joughin, I. (2002) Ice-Sheet Velocity Mapping: A Combined Interferometric and Speckle-Tracking Approach. Annals of Glaciology, 34, 195-201. http://dx.doi.org/10.3189/172756402781817978

[63] Griggs, J.A. and Bamber, J.L. (2009) A New 1 km Digital Elevation Model of Antarctica Derived from Combined Radar and Laser Data_-Part 2: Validation and Error Estimates. The Cryosphere, 3, 113-123. http://dx.doi.org/10.5194/tc-3-113-2009

[64] Helm, V., Humbert, A. and Miller, H. (2014) Elevation and Elevation Change of Greenland and Antarctica Derived from CryoSat-2. The Cryosphere, 8, 1539-1559. http://dx.doi.org/10.5194/tc-8-1539-2014

[65] Beck, I., Ludwig, R., Bernier, M., Strozzi, T. and Boike, J. (2015) Vertical Movements of Frost Mounds in Sub-Arctic Permafrost Regions Analyzed Using Geodetic Survey and Satellite Interferometry. Earth Surface Dynamics Discussions, 3, 251-283. http://dx.doi.org/10.5194/esurfd-3-251-2015

[66] Stenseng, L. (2009) Development of SAR Altimetry Mode Studies and Applications over Ocean, Coastal Zones and Inland Water. DTU-Space, National Space Institute, Denmark. ftp://ftp.space.dtu.dk/pub/SAMOSA/WP8-Technical Note v1.1.pdf

[67] Rao, Y.S., Venkataraman, G. and Rao, K.S. (2005) Application of SAR Interferometry for Himalayan Glaciers. Proceedings of Fringe 2005 Workshop, Frascati, 28 November-2 December 2005. http://earth.esa.int/workshops/fringe2005/proceedings/papers/138 venkataraman.pdf

[68] Dunse, T., Schellenberger, T., Hagen, J.O., Kaab, A., Schuler, T.V. and Reijmer, C.H. (2015) Glacier-Surge Mechanisms Promoted by a Hydro-Thermodynamic Feedback to Summer Melt. The Cryosphere, 9, 197-215. http://dx.doi.org/10.5194/tc-9-197-2015

[69] Zhou, C., Deng, F., Wan, L., Wang, Z., Dongchen, E. and Zhou, Y. (2014) Application of Synthetic Aperture Radar Remote Sensing in Antarctica. Proceedings of SPIE, Remote Sensing of the Environment: 18th National Symposium on Remote Sensing of China, 9158, Article ID: 91580L. http://dx.doi.org/10.1117/12.2063869 